\title{
CULTURE OF EXPLANTED RAT EMBRYOS IN ROTATING TUBES
}

\author{
D. A. T. NEW, P. T. GOPPOLA AND S. TERRY
}

Physiological Laboratory, Cambridge CB2 3EG

(Received 6th April 1973)

Various methods have been developed in recent years for growing postimplantation rat and mouse embryos in culture. Young embryos-up to early somite stages-grow well in static medium, e.g. simple watch-glass cultures (New, 1966; Steele, 1972). Older embryos require flowing medium, as in the culture systems of New (1967), Tamarin \& Jones (1968), Robkin, Shepard \& Tanimura (1972) and Cockroft (1973). These methods and some of their applications have been reviewed by New (1973).

Recently, a simpler technique for maintaining embryos in flowing medium has proved useful in this laboratory (New \& Brent, 1972; New \& Mizell, 1972). It consists of the culture of free-floating embryos in a constantly rotated tube which contains serum and an appropriate gas phase. We give here a short description of the method and a comparison of the results with those of the 'circulator' method (New, 1967).

Embryos, together with the placentae and embryonic membranes, are removed from the pregnant uterus and dissected from the surrounding decidua as described previously (New, 1966, 1971). Reichert's membrane is torn open and may be largely trimmed away, care being taken not to damage the placental area. The embryos, with visceral yolk-sac and allantoic placenta intact, are then transferred to the nutrient medium (rat serum containing $50 \mu \mathrm{g}$ streptomycin/ $\mathrm{ml}$ ) in the culture tube.

Culture tubes of various sizes may be used, depending on the number and size of the embryos. We have used standard cylindrical glass specimen tubes of approximately $2.5 \mathrm{~cm}$ diameter $\times 5 \mathrm{~cm}$ or $7.5 \mathrm{~cm}$ length, with sufficient serum ( 7 to $8 \mathrm{ml}$ in the shorter tubes, 10 to $12 \mathrm{ml}$ in the longer) to fill about half the available volume (Text-fig. Ia). Each tube is provided with a silicone rubber bung but, before inserting it completely, the gas phase of the culture $\left(5 \% \mathrm{CO}_{2}\right.$ in air, or $5 \% \mathrm{CO}_{2}: 95 \% \mathrm{O}_{2}$ ) is introduced through a fine sterile pipette inserted between the bung and wall of the tube; a gentle flow of gas is essential to avoid creating turbulence and damaging the embryos. After withdrawal of the gas pipette, the bung is tightly pressed home and sealed in with tape. It is important that the bung should have only a slight taper and should fit closely to the glass throughout its length, or the younger embryos can be trapped, during culture, in any space between bung and tube. As an alternative to specimen tubes, small glass bottles with a ground stopper sealed with silicone grease (Text-fig. Ib) also give satisfactory results. 


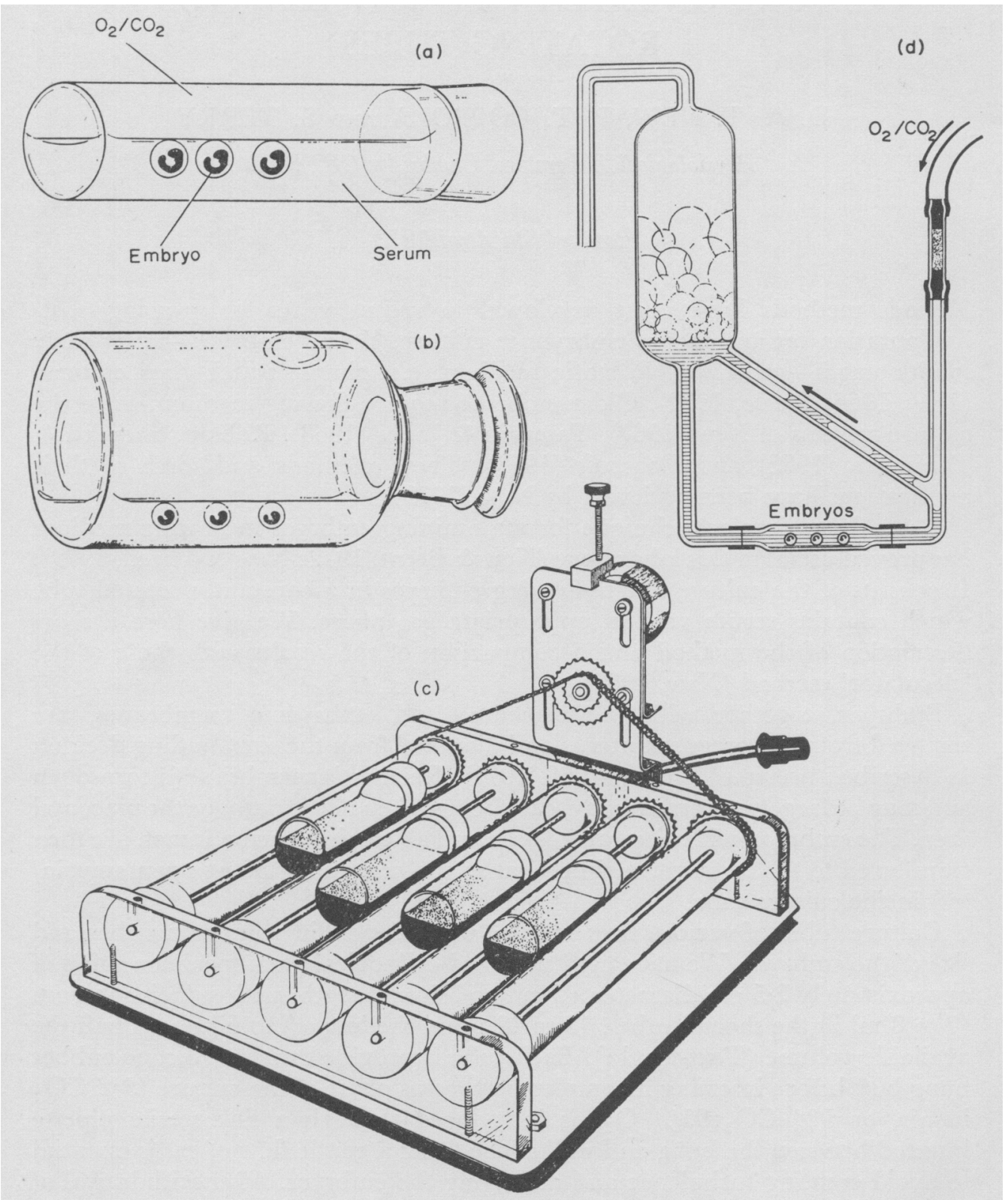

Text-Fig. 1. ( $a$ and $b)$ Two types of roller-tube culture chambers $(\times 0 \cdot 7)$. (c) Roller apparatus. (d) A 'circulator' culture system $(\times 0.4)$. 
The tubes are rotated continuously throughout incubation. For this purpose, an apparatus (Text-fig. 1c) consisting of five cylindrical perspex rollers (20 $\mathrm{cm} \times 3 \mathrm{~cm}$ diameter) powered by a small electric motor through a chain drive was used. This apparatus can accommodate up to twelve $2.5 \times 5 \mathrm{~cm}$ tubes and is compact enough (base $25 \mathrm{~cm}$ square) to be placed in a standard bench incubator. A simple gearing system allows for a choice of rotation speeds.

In preliminary trials, rat embryos were explanted and placed in culture at $9 \frac{1}{2}, 10 \frac{1}{2}$ and $11 \frac{1}{2}$ days of gestation. (Zero time was regarded as midnight preceding the morning on which spermatozoa were found in the vagina.) In general, development in the roller tubes was similar to that described previously for embryos cultured by the 'circulator' method (New, 1967; New \& Coppola, 1970) in which embryos, anchored within a culture chamber by their Reichert's

Table 1. Comparison of growth (protein content) and development (somite number) of rat embryos cultured in roller tubes and circulators

\begin{tabular}{|c|c|c|c|c|c|c|}
\hline $\begin{array}{c}\text { Age at } \\
\text { explantation } \\
\text { (days) }\end{array}$ & $\begin{array}{l}\text { Duration } \\
\text { of culture } \\
\quad(h r)\end{array}$ & $\begin{array}{l}\text { Culture } \\
\text { method }\end{array}$ & $\begin{array}{l}\text { No. of } \\
\text { embryos }\end{array}$ & $\begin{array}{c}\text { Final } \\
\text { somites } \\
(\text { mean } \pm S . E .)\end{array}$ & $\begin{array}{c}\text { Final } \\
\text { protein }(\mu g) \\
(\text { mean } \pm S . E .)\end{array}$ & $\begin{array}{l}\mathbf{P} \text { for } \\
\text { difference } \\
\text { in protein }\end{array}$ \\
\hline $10 \frac{1}{2}$ & 24 & $\begin{array}{l}\text { Roller tube* } \\
\text { Circulator }\end{array}$ & $\begin{array}{l}18 \\
18\end{array}$ & $\begin{array}{l}22 \pm 0 \cdot 7 \\
22 \pm 0.5\end{array}$ & $\begin{array}{l}147 \pm 9 \\
138 \pm 3\end{array}$ & $P>0 \cdot 10$ \\
\hline $10 \frac{1}{2}$ & 48 & $\begin{array}{l}\text { Roller tube* } \\
\text { Circulator }\end{array}$ & $\begin{array}{l}15 \\
15\end{array}$ & $\begin{array}{l}28 \pm 0.7 \\
32 \pm 0.4\end{array}$ & $\begin{array}{l}333 \pm 18 \\
505 \pm 18\end{array}$ & $P<0.001$ \\
\hline $11 \frac{1}{2}$ & 24 & $\begin{array}{l}\text { Roller tube* } \\
\text { Circulator }\end{array}$ & $\begin{array}{l}28 \\
28\end{array}$ & $\begin{array}{l}34 \pm 0 \cdot 3 \\
35 \pm 0 \cdot 4\end{array}$ & $\begin{array}{l}576 \pm 25 \\
749 \pm 27\end{array}$ & $P<0.001$ \\
\hline $11 \frac{1}{2}$ & 42 to 46 & $\begin{array}{l}\text { Roller tube* } \\
\text { Circulator }\end{array}$ & $\begin{array}{l}42 \\
32\end{array}$ & $\begin{array}{l}39 \pm 0.6 \\
40 \pm 0.4\end{array}$ & $\begin{array}{r}708 \pm 31 \\
1042 \pm 29\end{array}$ & $P<0.0001$ \\
\hline $11 \frac{1}{2}$ & 44 & $\begin{array}{l}\text { Roller tube* } \\
\text { Roller tube } \dagger \\
\text { Circulator }\end{array}$ & $\begin{array}{l}15 \\
18 \\
14\end{array}$ & $\begin{array}{l}40 \pm 0.7 \\
42 \pm 0.7 \\
42 \pm 0.9\end{array}$ & $\left.\begin{array}{r}824 \pm 80 \\
1148 \pm 75 \\
1193 \pm 82\end{array}\right\}$ & $\begin{array}{l}P<0.01 \\
P>0.10\end{array}$ \\
\hline
\end{tabular}

* Tube $2.5 \mathrm{~cm}$ diameter. About half the available volume of the tube was filled with serum. Rotated at 55 to $70 \mathrm{rev} / \mathrm{min}$.

$\dagger$ Bottle $4 \mathrm{~cm}$ diameter, containing $12 \mathrm{ml}$ serum and $60 \mathrm{ml}$ gas phase. Rotated at 40 to $45 \mathrm{rev} / \mathrm{min}$.

membrane, are bathed by a continuous flow of oxygenated serum (Text-fig. 1d). The yolk-sac expanded and the embryonic and yolk-sac blood circulations were well maintained. Embryos explanted at $9 \frac{1}{2}$ days (headfold stage) and cultured for 60 to $70 \mathrm{hr}$ reached early limb-bud stages with 26 to 28 somites. Embryos explanted at $11 \frac{1}{2}$ days (22 to 28 somites) and cultured for 40 to $50 \mathrm{hr}$ maintained their blood circulation for about $30 \mathrm{hr}$ and developed 40 to 42 somites.

The results of a more detailed comparison of growth in roller tubes with that in circulators are shown in Table 1. Embryos were explanted from pregnant rats at $10 \frac{1}{2}$ days and $11 \frac{1}{2}$ days gestation and each litter was divided between the roller tube and circulator cultures. Two or three embryos were placed in each roller tube or circulator and the volume of serum adjusted to give 2.5 to $3 \mathrm{ml}$ for each 101 -day embryo and 3 to $4 \mathrm{ml}$ for each $11 \frac{1}{2}$-day embryo. The flow rate in the circulators was maintained at around $15 \mathrm{ml}$ serum $/ \mathrm{min}$ and the roller tubes were rotated at 40 to $70 \mathrm{rev} / \mathrm{min}$ (see notes to Table 1). The gas phase of the cultures of $10 \frac{1}{2}$-day embryos, in circulators or roller tubes, was initially $5 \%$ $\mathrm{CO}_{2}$ in air, replaced after $24 \mathrm{hr}$ with $5 \% \mathrm{CO}_{2}: 95 \% \mathrm{O}_{2}$. The gas phase for the 
$11 \frac{1}{2}$-day embryos in circulators was $5 \% \mathrm{CO}_{2}: 95 \% \mathrm{O}_{2}$ throughout the culture period; the roller tubes containing $11 \frac{1}{2}$-day embryos were gassed with this mixture initially and again after $24 \mathrm{hr}$. The final number of somites formed in each embryo and the protein content (of the embryo alone, dissected free of membranes) was recorded. Protein was assessed by the colorimetric method of Lowry, Rosebrough, Farr \& Randall (1951).

The results show that (i) tubes of $2.5 \mathrm{~cm}$ diameter are as good as circulators for growing 101 -day embryos for $24 \mathrm{hr}$, but are less effective for older embryos; (ii) tubes (bottles) of $4 \mathrm{~cm}$ diameter are as good as circulators for growing $11 \frac{1}{2}$ day embryos.

The inferior growth of $11 \frac{1}{2}$-day embryos in the smaller tubes seems likely to be the result of an inadequate volume of gas phase (10 to $15 \mathrm{ml})$. Although the tubes were initially gassed with $5 \% \mathrm{CO}_{2}: 95 \% \mathrm{O}_{2}$, after $24 \mathrm{hr}$, the oxygen level had fallen to about $70 \%$ and the $\mathrm{pH}$ of the serum to $7 \cdot 1$ (as compared with $\mathrm{pH}$ 7.4 to 7.5 in the circulators). In the larger tubes, with a gas volume of about $60 \mathrm{ml}$, changes in $\mathrm{pH}$ and oxygen level were much smaller.

It appears that roller tubes are as effective as more elaborate culture methods for maintaining the growth of embryos, provided tubes of adequate size are used for the particular stage of embryonic development. Roller tubes are inconvenient for continuous or frequent observation of the embryos during culture but, where the main object is to assess the final result of a treatment (e.g. a test substance added to the culture medium) on embryonic development, the simplicity of the method has much to recommend it.

\section{REFERENCES}

Cockroft, D. L. (1973) Development in culture of rat foetuses explanted at $12 \frac{1}{2}$ and $13 \frac{1}{2}$ days of gestation. F. Embryol. exp. Morph. 29, 473.

Lowry, O. H., Rosebrough, N. J., FarR, A. L. \& Randall, R. J. (1951) Protein measurements with the Folin phenol reagent. F. biol. Chem. 193, 265.

New, D. A. T. (1966) The culture of vertebrate embryos. Logos Press, London.

NEw, D. A. T. (1967) Development of explanted rat embryos in circulating medium. F. Embryol. exp. Morph. 17, 513.

NEw, D. A. T. (1971) Methods for the culture of post-implantation embryos of rodents. In: Methods in Mammalian Embryology, p. 305. Ed. J. C. Daniel, Jr. W. H. Freeman, San Francisco.

New, D. A. T. (1973) Studies on mammalian fetuses in vitro during the period of organogenesis. In: The Mammalian Fetus in Vitro, p. 15. Ed. C. R. Austin. Chapman \& Hall, London.

NEw, D. A. T. \& BRENT, R. L. (1972) Effect of yolk-sac antibody on rat embryos grown in culture. F. Embryol. exp. Morph. 27, 543.

New, D. A. T. \& Coppola, P. T. (1970) Effects of different oxygen concentrations on the development of rat embryos in culture. F. Reprod. Fert. 21, 109.

New, D. A. T. \& Mizeli, M. (1972) Opossum fetuses grown in culture. Science, N. Y. 175, 533.

Robkin, M. A., Shepard, T. H. \& TANIMURa, T. (1972) A new in-vitro culture technique for rat embryos. Teratology, 5, 367.

STEELE, G. E. (1972) Improved development of rat "egg-cylinders" in vitro as a result of fusion of the heart primordia. Nature, Lond. New Biology, 237, 150.

Tamarin, A. \& Jones, K. W. (1968) A circulating medium system permitting manipulation during culture of postimplantation embryos. Acta Embryol. exp. Morph. 10, 288. 